\title{
REVIEW
}

\section{Neuroendocrine neoplasm update: toward universal nomenclature}

\author{
Guido Rindi1,2,3 and Frediano Inzani1,3 \\ ${ }^{1}$ Fondazione Policlinico Universitario A. Gemelli IRCCS, Rome, Italy \\ 2Università Cattolica del Sacro Cuore, Rome, Italy \\ ${ }^{3}$ ENETS Center of Excellence, Neuroendocrine Tumour (NET) Center, Rome, Italy
}

Correspondence should be addressed to G Rindi: guido.rindi@unicatt.it

\begin{abstract}
Neuroendocrine neoplasia is described in almost every tissue, either in the pure endocrine organs, the nerve structures or in the so-called diffuse neuroendocrine system. The current nomenclature contains time-honored, widely accepted definitions; however, it is different according to anatomical sites. Diverse definitions may generate confusion and non-standard patient management. The International Agency for Research on Cancer - World Health Organization (IARC-WHO) proposed a framework for universal classification of neuroendocrine neoplasia. Evidence indicates that neuroendocrine cancer is composed by cells with a distinctive phenotype characterized by the expression of general and specific neuroendocrine markers. The neuroendocrine phenotype is indicated as descriptor of a unique cancer category, now recommended for all organs as neuroendocrine neoplasm. Evidence indicates that neuroendocrine neoplasia may be well or poorly differentiated, with diverse incidence and prevalence in different organs. It is proposed that the well-differentiated neoplasm is universally defined as neuroendocrine tumor (NET) and the poorly differentiated as neoplasm neuroendocrine carcinoma (NEC). Evidence indicates that a cancer grading tool based on a proliferation measure by mitotic count, Ki67 \% and/or necrosis assessment is useful to predict NET patient behavior. It is proposed to utilize this tool for grading NET universally, with site-specific cut-offs to be defined. It is also acknowledged that significant biological site-specific differences exist. It is recommended that current pathology reports contain this classification together with the current traditional classifiers. This IARC-WHO common classification framework for neuroendocrine neoplasm aims at uniformizing nomenclature toward different organs and at fostering the definition of a similar site-specific gene signature.
\end{abstract}

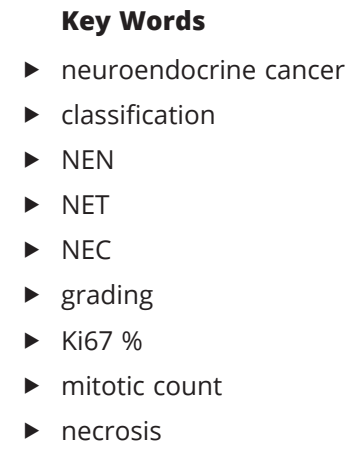

Endocrine-Related Cancer (2020) 27, R211-R218

\section{Background}

It was less than one century ago that Friederich Feyrter proposed the existence of a diffuse (neuro)endocrine cell system within the human body (Feyrter 1938). The idea was based on the fact that rare cells with peculiar and similar staining properties were observed in most organs. The identified phenotype was supposed to equalize a specific cell function. This concept was substantially confirmed, though with a higher degree of complexity, in the years after. It is now recognized that neuroendocrine cells indeed exert regulatory function at distance on target organs (endocrine function), but also at local organ levels (paracrine function) and often of unknown (c) 2020 Society for Endocrinology Published by Bioscientifica Ltd. Printed in Great Britain 
specific significance. The acid-gastrin-histamine axis is a well-known example of regulatory function supported by neuroendocrine cells at local level. Other cell types exert classical endocrine systemic function as in the pituitary or in the islet of Langerhans of the pancreas. Neuroendocrine cells in the gut develop via a complex gene hierarchy, tightly regulated by local specific physiological stimuli (Gehart et al. 2019). Overall, these features make this cell population unique both functionally and phenotypically. The phenotype is characterized by the expression of markers of neuroendocrine differentiation, either general (i.e. present in all different cell types of all organs) like synaptophysin and the chromogranin gene peptides (e.g. chromogranin A) or specific (i.e. present only in specific cell types) and usually hormones (Rindi \& Wiedenmann 2012). Specific hormones are differently expressed in different cell types, often with specific organ segregation (e.g. histamine in enterochromaffin-like, ECL, cells of the stomach only). Nonetheless, a high degree of cell plasticity is recognized. While neuroendocrine markers both specific and general are expressed in elements of the central and peripheral nervous system, cells with the previously mentioned neuroendocrine phenotype are epithelial.
These cell types or, perhaps, neuroendocrine-committed cells do transform, generating neoplasms. Neoplasms made by cells with a neuroendocrine phenotype are today defined as neuroendocrine neoplasia (NEN). Similar to neuroendocrine cells, NEN are observed in pure endocrine organs (anterior pituitary, parathyroid, thyroid and adrenals), in pure nerve structures and in organs hosting the diffuse neuroendocrine cell system (skin, upper airways and lung, breast, digestive, urinary and reproductive organs) (Inzani \& Rindi 2017). Though some subtle histological features may characterize well-differentiated neoplasia at specific anatomical site, in general, NEN display a distinctive and unique morphology that is consistently similar in all organs and virtually unattributable to any given organ if not tested for site-specific antigens (i.e. hormones or transcription factors) (Fig. 1).

\section{Why a common classification for neuroendocrine neoplasia}

\section{Functioning NEN}

Along the past century, NEN were recognized and given different names based on the knowledge available at the time of their first description and often paralleling the

\section{NEN}

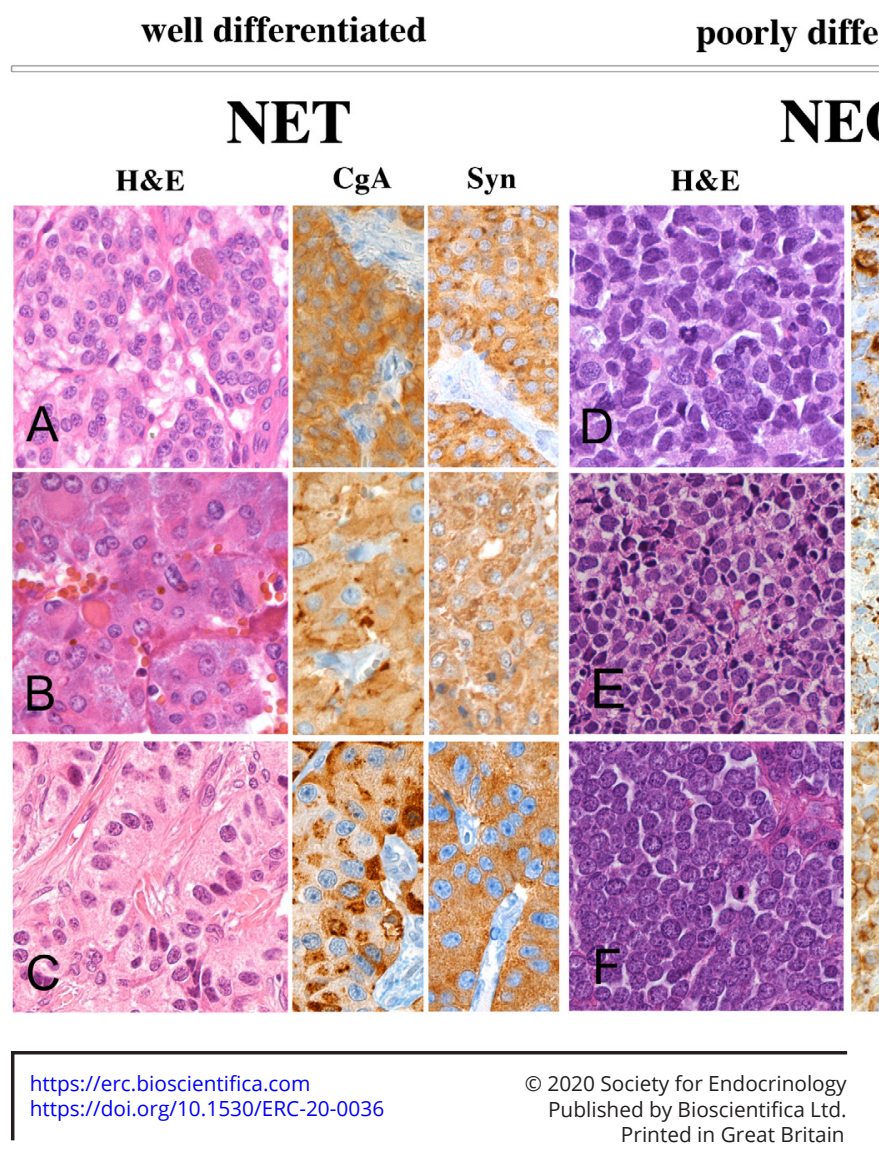

\section{Figure 1}

The neuroendocrine neoplasm category. The neuroendocrine cancer is defined as neuroendocrine neoplasm (NEN), a category based on the common expression of the general markers of neuroendocrine differentiation chromogranin A and synaptophysin. NEN definition embraces the two families (classes) of the well-differentiated lesions, defined as neuroendocrine tumor (NET), and the poorly differentiated lesion, defined as neuroendocrine carcinoma (NEC). (A, B and C) NET G1 displays a trabecular/insular structure, in absence of necrosis, and is composed of epithelial cells with abundant cytoplasm, low degree of atypia, low, if any, mitotic activity and intense expression of the general neuroendocrine markers chromogranin $A$ and synaptophysin. (A) Lung typical carcinoid; (B) pheochromocytoma; (C) insulinoma. (D, E and F) NEC displays a solid structure with abundant and/or single cell necrosis and is composed of epithelial cells with scant (small cell type) or abundant (large cell type) cytoplasm, severe atypia, frequent mitoses (often atypical) and evident, though low intensity, expression of the general neuroendocrine marker chromogranin A and synaptophysin. (D) Pulmonary NEC, small cell type (small cell lung carcinoma, SCLC); (E) gastric NEC, small cell type; (F) cutaneous NEC (Merkel cell carcinoma). 
discovery of peptide hormones and their function. All of this resulted in the building of a cancer nomenclature that mostly reflected the cancer's endocrine function, usually different and site-specific. So, pheochromocytoma was named in the adrenals for tumors associated with catecholamine-driven symptoms, insulinomas in the pancreas for tumors associated to hyper-insulinemic hypoglycemia, carcinoid in the small intestine for tumors determining flushing and diarrhea and so on.

As a general rule, functioning NEN are welldifferentiated neoplasms composed by cells that display abnormal proliferation control but retain all mechanisms of hormone production in the absence of secretion control. Indeed, functioning NEN cells do resemble the normal counterpart and similarly express at high levels the same neuroendocrine connoting antigens. Only in very rare instances, hyperfunction hormonal syndromes associate with aggressive NEN cancer as, for example, in the welldifferentiated parathyroid carcinoma and sometimes in the poorly differentiated small cell lung carcinoma. As a consequence, the clinical behavior of functioning NEN in most cases is mainly dictated by the hormone syndrome they determine rather than by the biological features intrinsic to the cancer growth. The prognosis of patients with functioning NEN therefore largely depends on how effective the control of symptoms is, as determined by the abnormal circulating hormone levels.

\section{Non-functioning NEN}

For a long time, it was felt that all NENs were functional, that is, determine syndrome(s) due to unregulated hormone(s) release. This proved untrue and it is now recognized that the majority of NEN is non-functioning. This means that NEN is composed by cells with a neuroendocrine phenotype, though uncapable of producing/releasing hormones and thus does not determine a hormonal syndrome. Non-functioning NEN is recognized in most organs, either in classical endocrine organs, like the anterior pituitary or the pancreas, or in organs with other major functions, that is, the lung and the gut (Dasari et al. 2017). Similar to functioning NEN, the largest fraction of non-functioning NEN is well differentiated and its organ distribution follows the normal cell-type distribution (Rindi \& Wiedenmann 2012). The morphology and antigen expression pattern of non-functioning welldifferentiated NEN are overlapping to those of functioning NEN. Even the expression of hormones may be observed, though usually less intense and diffuse. Overall, it is substantially impossible to distinguish non-functioning and functioning well-differentiated NEN based on pure morphology.

Though less aggressive overall when welldifferentiated, non-functioning NEN behave similarly to any other epithelial cancer following the usual cancer route of growth-invasion-metastasis deposition. At the same time, prognosis depends on NEN cancer biology and displays a range of clinical behaviors from low to high grade malignancy. Indeed, a large fraction of well-differentiated NEN behave as low-grade malignant if not indolent. In fact, the definition of benign epithelial neoplasm (adenoma) was traditionally preferred for some of them. This is the case for the anterior pituitary, where NEN was defined adenoma in most cases (DeLellis et al. 2004). The clinical observation of rare adenomas that behave more aggressively, however, induced the introduction of the definition 'atypical adenomas' (ibidem). In this case, the connoting adjective 'atypical' implied the fact that these adenomas did not behave like the majority of NEN of the anterior pituitary and outlined their aggressive and malignant behavior. This was also the case for the lung, where the definitions of typical and atypical carcinoid still hold (Travis et al. 2015).

NEN may also display high grade malignancy. Indeed, a deadly cancer like the small cell carcinoma of the lung and of other organs is usually composed of cells with a neuroendocrine phenotype. It is therefore NEN in nature, but poorly differentiated in phenotype and considered closer to the multipotent stem cell in origin (Rickman et al. 2017, Rudin et al. 2019a,b).

\section{Proliferation, patient prognosis and NEN}

It has been recognized that the morphological criteria usually adopted for other epithelial cancers do not hold the same efficacy for grading purposes in NEN. It is well known, for instance, that the severe cell atypia observed in pheochromocytoma does not necessarily reflect higher malignancy but is considered a regressive change. When NEN cells retain morphological features highly similar to the normal neuroendocrine cell counterpart and low to moderate degree of cell atypia, NEN is defined as well differentiated. For well-differentiated NEN of the lung and the digestive system, it was demonstrated that prognostically effective grading parameters associate with proliferation, that is, mitotic count and proliferation index as measured by Ki67 expression (Travis et al. 2015, WHO $2019 b$ ). Necrosis, a measure of non-effective sustained cancer growth, proved also equally predictive in the lung (Travis et al. 2015). 
When NEN cells do not display the morphological features of normal neuroendocrine cells (i.e. are well differentiated) but show severe cell atypia, NEN is defined as poorly differentiated. Poorly differentiated NEN displays the highest degree of proliferation rate, is the most aggressive type of neuroendocrine cancer and shares the same risk factors and etiology of non-neuroendocrine cancer when known (e.g. the small cell lung cancer strongly associates with smoking similar to other types of bronchogenic carcinoma).

\section{Genetics, patient prognosis and NEN}

The spectrum of aggressivity recognized in NEN reflects the degree of gene derangement at its basis. Accumulating evidence indicates that well-differentiated, low-grade malignant, well-differentiated NEN has a low number of gene alterations, low mutational burden and almost no involvement of classic cancer drivers (Laddha et al. 2019, Priestley et al. 2019, Neou et al. 2020). A recent genome wide analysis on a large cohort of solid cancers, in fact, showed that well-differentiated NEN of the pancreas show the lowest frequency of known driver mutations (ICGC/TCGA Pan-Cancer Analysis of Whole Genomes Consortium 2020).

On the contrary, the poorly differentiated high grade NEN has a high degree of gene abnormality most often involving classical drivers including TP53 and $R b$ (Rekhtman et al. 2016, Konukiewitz et al. 2017, Shamir etal. 2019). This genetic background was also consistently found in mixed neuroendocrine, non-neuroendocrine cancers pointing to a common genetic and lineage origin for both components (Jesinghaus et al. 2017, Woischke et al. 2017). These data strongly suggest poorly differentiated high grade NEN to be a cancer disease closely related to the exocrine cancer. This makes the poorly differentiated NEN a separate cancer entity as compared to well-differentiated forms. In rare instances, in the pancreas and lung, NEN cell features and gene alteration burden were reported to increase along the NEN disease spectrum and the cancer progression and sometimes associated to therapy-induced pressure (Rickman et al. 2017, Raj et al. 2018, Alcala et al. 2019)

Overall, similar to other cancer types (e.g. adenocarcinoma, squamous cell carcinoma), NEN are now recognized as a category variant that has its own specific features (the neuroendocrine phenotype) and can be found almost everywhere in the body. Similar to any other cancer type, NEN behave and retain tissue-specific characters depending on the organ in which it grows.
Based on this, the International Agency for Research on Cancer-World Health Organization (IARC-WHO) felt it necessary to uniform the nomenclature of NEN in various organs and to provide direct instruction for diagnosis and classification (Rindi et al. 2018a).

\section{Proposed classification framework}

The key feature of the NEN category is the expression of the neuroendocrine markers chromogranins (usually chromogranin A) and synaptophysin at any anatomical site, in some also of CD56 (lung). Their expression may vary according to anatomical sites and degrees of differentiation (Fig. 1).

Current classifications utilize different nomenclature for NEN in different organs (Table 1) (Travis et al. 2015, Moch et al. 2016, El-Naggar et al. 2017, Lloyd et al. 2017, Elder et al. 2018, WHO 2019a,b). The proposed classification framework (Table 2) recognizes two families (classes) of well and poorly differentiated NEN as clearly distinguished by genetic, morphology and clinical behavior (Kloppel 2017). Well differentiated NENs are defined as neuroendocrine tumor (NET), while poorly differentiated are defined as neuroendocrine carcinoma (NEC). It is acknowledged that in different organs the existence of both classes and their prevalence may be extremely variable. Within each organ are further defined tumor types that represent specific diagnostic entities with relevant ICD-O codes. Variants are also proposed. NET is further graded according to proliferation into G1-G3, while NEC are by default G3 and further sub-typed into small and large cell carcinoma (SC and LC, NEC). NEC is, in fact, poorly differentiated, by definition high grade, and thus not graded to stress the substantial difference vs well-differentiated forms. The fact that NEC is not graded as G3 was intended to avoid confusion vs the high grade well-differentiated NET G3.

As exemplification of this framework when applied to the lung, the well-differentiated NET class is defined as pulmonary NET (currently defined as 'typical carcinoid' and 'atypical carcinoid') and further graded as G1 and G2. The NET G3 of the lung is still under study with reported mounting evidence (Dinter et al. 2019, Kasajima et al. 2019, Oka et al. 2019, Dermawan \& Farver 2020). The poorly differentiated NEC class is as defined small cell lung carcinoma (pulmonary NEC small cell type, SCLC) and pulmonary large cell neuroendocrine carcinoma (pulmonary NEC large cell type, LCNEC).

Grading of NET is performed using the proliferation parameters of mitotic count per $2 \mathrm{~mm}^{2}$, Ki67 \% and the 
Table 1 Current NEN classifiers with classification details according to current WHO blue books.

\begin{tabular}{|c|c|c|c|c|}
\hline \multirow[b]{3}{*}{ Site } & \multicolumn{3}{|l|}{ Classifiers } & \multirow{3}{*}{$\begin{array}{l}\text { WHO Blue } \\
\text { Book } \\
\text { Reference } \\
\end{array}$} \\
\hline & \multicolumn{2}{|l|}{ Well differentiated } & \multirow{2}{*}{$\begin{array}{l}\text { Poorly differentiated } \\
\text { High grade } \\
\end{array}$} & \\
\hline & Low grade & Intermediate/high grade & & \\
\hline Pituitary & $\begin{array}{l}\text { Pituitary adenoma } \\
\text { (monomorphic, rare } \\
\text { mitoses, low Ki67) }\end{array}$ & $\begin{array}{l}\text { Pituitary carcinoma (atypical } \\
\text { features; metastasis) }\end{array}$ & nd & WHO 2017 \\
\hline Thyroid & \multicolumn{2}{|c|}{ Medullary thyroid carcinoma } & nd & WHO 2017 \\
\hline Parathyroid & $\begin{array}{l}\text { Adenoma (encapsulated } \\
\text { neoplasm, usually } \\
\text { single gland) }\end{array}$ & $\begin{array}{l}\text { Carcinoma (invasive growth } \\
\text { involving adjacent structures, } \\
\text { capsular and/or extracapsular } \\
\text { blood vessels or perineural } \\
\text { spaces and/ or presence of } \\
\text { metastases) }\end{array}$ & nd & WHO 2017 \\
\hline $\begin{array}{l}\text { Lung and } \\
\text { thymus }\end{array}$ & $\begin{array}{l}\text { Typical carcinoid (carcinoid } \\
\text { morphology and }<2 \text { mitoses } / 2 \\
\mathrm{~mm}^{2} ; \text { no necrosis) }\end{array}$ & $\begin{array}{l}\text { Atypical carcinoid (carcinoid } \\
\text { morphology and } 2-10 \\
\text { mitoses } / 2 \mathrm{~mm}^{2} \text { and/or } \\
\text { necrosis) }\end{array}$ & $\begin{array}{l}\text { SCLC-LCNEC (small or } \\
\text { large cells type; } \\
>10 \text { mitoses } / 2 \mathrm{~mm}^{2} \\
\text { and necrosis) }\end{array}$ & WHO 2015 \\
\hline $\begin{array}{l}\text { Digestive tract } \\
\text { and pancreas }\end{array}$ & $\begin{array}{l}\text { NE tumor - NET G1 (mitotic } \\
\text { count }<2 / 10 \text { HPF or Ki67 <3\%) }\end{array}$ & $\begin{array}{l}\text { NE Tumor - NET G2 and } \\
\text { G3 (G2 mitotic count } \\
\text { 2-20/10 HPF or Ki67 3-20\%; } \\
\text { G3 mitotic count > 20/10 HPF } \\
\text { or Ki67 >20\%) }\end{array}$ & $\begin{array}{l}\text { NEC G3 (small or large } \\
\text { cells type; mitotic } \\
\text { count }>20 / 10 \text { HPF } \\
\text { or Ki } 67>20 \% \text { ) }\end{array}$ & WHO 2019 \\
\hline Head and neck & $\begin{array}{l}\text { Well differentiated } \\
\text { carcinoma (grade I: minimal } \\
\text { nuclear atypia; }<2 \text { mitoses/2 } \\
\mathrm{mm}^{2} ; \text { no necrosis) }\end{array}$ & $\begin{array}{l}\text { Moderately differentiated } \\
\text { carcinoma (grade I: more } \\
\text { nuclear atypia; } 2-10 \text { mitoses/ } \\
2 \mathrm{~mm}^{2} \text { and/or necrosis) }\end{array}$ & $\begin{array}{l}\text { Poorly differentiated } \\
\text { carcinoma (small or } \\
\text { large cells type; } \\
>10 \text { mitoses } / 2 \mathrm{~mm}^{2} \\
\text { and necrosis) }\end{array}$ & WHO 2017a \\
\hline $\begin{array}{l}\text { Adrenal and } \\
\text { extra-adrenal } \\
\text { paraganglia }\end{array}$ & \multirow{2}{*}{\multicolumn{2}{|c|}{ Pheochromocytoma and extra-adrenal paraganglioma }} & nd & WHO 2017 \\
\hline Skin & & & Merkel cell carcinoma & WHO 2018 \\
\hline $\begin{array}{l}\text { Female genital } \\
\text { organs }\end{array}$ & Low-grade NE tumor G1 & $\begin{array}{l}\text { Low-grade NE tumor } \\
\text { G2 (greater atypia, } \\
\text { mitoses and /or necrosis) }\end{array}$ & $\begin{array}{l}\text { High-grade NE } \\
\text { carcinoma G3 (small } \\
\text { and large cell type) }\end{array}$ & WHO 2015 \\
\hline Breast & $\begin{array}{l}\text { NE tumor G1 (Nottingham } \\
\text { grading) }\end{array}$ & $\begin{array}{l}\text { NE tumor G2 } \\
\text { (Nottingham grading) }\end{array}$ & $\begin{array}{l}\text { NE carcinoma (small } \\
\text { and large cell type) }\end{array}$ & WHO 2019a \\
\hline $\begin{array}{l}\text { Urinary system } \\
\text { and male } \\
\text { genital organs }\end{array}$ & \multicolumn{2}{|c|}{ Well differentiated NE tumor } & $\begin{array}{l}\text { NE carcinoma (large } \\
\text { and small cell } \\
\text { carcinoma (SmCC)) }\end{array}$ & WHO 2016 \\
\hline
\end{tabular}

WHO 2015: (Travis et al. 2015); WHO 2016: (Moch et al. 2016); WHO 2017: (Lloyd et al. 2017); WHO 2017a: (El-Naggar et al. 2017); WHO 2018: (Elder et al. 2018); WHO 2019: (WHO 2019b); WHO 2019a: (WHO 2019a). Adapted by permission from: Springer International Publishing, Diagnostic and Therapeutic Nuclear Medicine for Neuroendocrine Tumors, by K Pacak \& D Taïeb (Eds.), copyright 2017 (Inzani \& Rindi 2017).

nd: not described; NE: neuroendocrine; WHO: World Health Organization.

presence of necrosis. The parameter necrosis is only formally used in thoracic NEN. It is well known that evidence exists to support organ-specific cutoffs, like in the lung and the digestive system (Rindi et al. 2018b, Dermawan \& Farver 2020). For all other organs, such evidence needs to be built. In some areas like the pituitary, this classification is a recognized need and is under active investigation and debate by the Pituitary Society and the Pituitary Pathology Club (Chiloiro et al. 2015, 2014, Asa et al. 2017, 2020, Ho et al. 2019, 2020). Challenges in adopting this new classification framework are expected for other classical endocrine organs too, where the malignancy prediction is difficult (e.g. the thyroid medullary carcinoma and the parathyroid adenoma/carcinoma). It is acknowledged

(c) 2020 Society for Endocrinology Published by Bioscientifica Ltd. Printed in Great Britain and stressed that significant biological differences exist between NENs of different organs, reflecting site-specific genetic differences. It is expected that site-specific genetic signatures may exist for NEN classes in various organs.

\section{Conclusions and recommendations}

Today, pathologists and clinicians rely on the blue books of the IARC-WHO for the classification of NEN in different organs. These classifications contain all details needed to perform accurate and meaningful diagnosis for the use of clinicians for the benefit of patients (Table 1). Its value is undisputed. Still, the current nomenclature contains 
Table 2 Proposed NEN classifiers as applied to selected sites in anatomical order top-down; the definition of grade for NET depends on accepted proliferation parameters that in many anatomical sites are lacking, while in others, that is, the lung and the digestive system, are available and defined in Table 1.

\begin{tabular}{|c|c|c|c|c|c|}
\hline Site & Category & Family & Type & Grade & Current terminology \\
\hline Pituitary & $\begin{array}{l}\text { Neuroendocrine } \\
\text { neoplasm (NEN) }\end{array}$ & $\begin{array}{l}\text { Neuroendocrine } \\
\text { tumor (NET) }\end{array}$ & Pituitary NET (PitNET) & $\begin{array}{l}\text { G1 } \\
\text { G2 }\end{array}$ & $\begin{array}{l}\text { Pituitary adenoma } \\
\text { High risk pituitary } \\
\text { adenoma }\end{array}$ \\
\hline \multirow[t]{2}{*}{$\begin{array}{l}\text { Head and } \\
\text { neck }\end{array}$} & \multirow[t]{2}{*}{$\begin{array}{l}\text { Neuroendocrine } \\
\text { neoplasm (NEN) }\end{array}$} & $\begin{array}{l}\text { Neuroendocrine } \\
\text { tumor (NET) }\end{array}$ & $H \& N a$ site NET & $\begin{array}{l}\text { G3 } \\
\text { G1 } \\
\text { G2 } \\
\text { G3 }\end{array}$ & $\begin{array}{l}\text { Pituitary carcinoma } \\
\text { Well differentiated } \\
\text { carcinoma } \\
\text { Moderately differentiated } \\
\text { carcinoma }\end{array}$ \\
\hline & & $\begin{array}{l}\text { Neuroendocrine } \\
\text { carcinoma (NEC) }\end{array}$ & $\begin{array}{l}\text { H\&Na site NEC small cell type } \\
\text { H\&Na site NEC large cell type }\end{array}$ & & $\begin{array}{l}\text { Poorly differentiated } \\
\text { carcinoma }\end{array}$ \\
\hline \multirow[t]{2}{*}{ Thyroid } & \multirow[t]{2}{*}{$\begin{array}{l}\text { Neuroendocrine } \\
\text { neoplasm (NEN) }\end{array}$} & $\begin{array}{l}\text { Neuroendocrine } \\
\text { tumor (NET) }\end{array}$ & Thyroid NET & \multirow[t]{2}{*}{$\begin{array}{l}\text { G1 } \\
\text { G2 } \\
\text { G3 }\end{array}$} & $\begin{array}{l}\text { Medullary thyroid } \\
\text { carcinoma }\end{array}$ \\
\hline & & $\begin{array}{l}\text { Neuroendocrine } \\
\text { carcinoma (NEC) }\end{array}$ & Thyroid NEC & & $\begin{array}{l}\text { Medullary thyroid } \\
\text { carcinoma } \\
\text { Small cell variant }\end{array}$ \\
\hline Parathyroid & $\begin{array}{l}\text { Neuroendocrine } \\
\text { neoplasm (NEN) }\end{array}$ & $\begin{array}{l}\text { Neuroendocrine } \\
\text { tumor (NET) }\end{array}$ & Parathyroid NET & $\begin{array}{l}\text { G1 } \\
\text { G2 } \\
\text { G3 }\end{array}$ & $\begin{array}{l}\text { Parathyroid adenoma } \\
\text { Parathyroid atypical } \\
\text { adenoma variant } \\
\text { Parathyroid carcinoma }\end{array}$ \\
\hline \multirow[t]{3}{*}{ Lung } & \multirow[t]{3}{*}{$\begin{array}{l}\text { Neuroendocrine } \\
\text { neoplasm (NEN) }\end{array}$} & $\begin{array}{l}\text { Neuroendocrine } \\
\text { tumor (NET) }\end{array}$ & Pulmonary NETb & $\begin{array}{c}\text { G1 } \\
\text { G2 } \\
\text { G3b }\end{array}$ & $\begin{array}{l}\text { Carcinoid } \\
\text { Atypical } \\
\text { Carcinoid }\end{array}$ \\
\hline & & \multirow[t]{2}{*}{$\begin{array}{l}\text { Neuroendocrine } \\
\text { carcinoma (NEC) }\end{array}$} & $\begin{array}{l}\text { SCLC } \\
\text { Pulmonary NEC small } \\
\text { cell typec }\end{array}$ & & $\begin{array}{l}\text { Small cell lung } \\
\text { carcinoma }\end{array}$ \\
\hline & & & Pulmonary NEC large cell type & & Large cell NE carcinoma \\
\hline \multirow[t]{2}{*}{ Thymus } & \multirow[t]{2}{*}{$\begin{array}{l}\text { Neuroendocrine } \\
\text { neoplasm (NEN) }\end{array}$} & $\begin{array}{l}\text { Neuroendocrine } \\
\text { tumor (NET) }\end{array}$ & Thymic NET & $\begin{array}{l}\text { G1 } \\
\text { G2 } \\
\text { G3 }\end{array}$ & $\begin{array}{l}\text { Carcinoid } \\
\text { Atypical } \\
\text { Carcinoidb }\end{array}$ \\
\hline & & $\begin{array}{l}\text { Neuroendocrine } \\
\text { carcinoma (NEC) }\end{array}$ & $\begin{array}{l}\text { Thymic NEC small cell type } \\
\text { Thymic NEC large cell type }\end{array}$ & & $\begin{array}{l}\text { Small cell carcinoma } \\
\text { Large cell NE carcinoma }\end{array}$ \\
\hline \multirow[t]{3}{*}{ Gut } & \multirow[t]{3}{*}{$\begin{array}{l}\text { Neuroendocrine } \\
\text { neoplasm (NEN) }\end{array}$} & $\begin{array}{l}\text { Neuroendocrine } \\
\text { tumor (NET) }\end{array}$ & GUT site ${ }^{d}$ NET & $\begin{array}{l}\text { G1 } \\
\text { G2 } \\
\text { G3 }\end{array}$ & $\begin{array}{l}\text { GUT sited NET G1 } \\
\text { GUT sited NET G2 } \\
\text { GUT sited NET G3 }\end{array}$ \\
\hline & & \multirow[t]{2}{*}{$\begin{array}{l}\text { Neuroendocrine } \\
\text { carcinoma (NEC) }\end{array}$} & GUT site ${ }^{d}$ NEC small cell type & & $\begin{array}{l}\text { GUT sited NEC }^{\text {NUTll cell type }} \\
\text { smal }\end{array}$ \\
\hline & & & GUT sited NEC large cell type & & $\begin{array}{l}\text { GUT sited NEC } \\
\text { large cell type }\end{array}$ \\
\hline \multirow[t]{4}{*}{ Pancreas } & \multirow{4}{*}{$\begin{array}{l}\text { Neuroendocrine } \\
\text { neoplasm (NEN) }\end{array}$} & \multirow{2}{*}{$\begin{array}{l}\text { Neuroendocrine } \\
\text { tumor (NET) }\end{array}$} & Pancreas NET (PanNET) & G1 & PanNET G1 \\
\hline & & & & $\begin{array}{l}\text { G2 } \\
\text { G3 }\end{array}$ & $\begin{array}{l}\text { PanNET G2 } \\
\text { PanNET G3 }\end{array}$ \\
\hline & & $\begin{array}{l}\text { Neuroendocrine } \\
\text { carcinoma (NEC) }\end{array}$ & Pancreas NEC small cell type & & $\begin{array}{l}\text { Pancreas NEC } \\
\text { small cell type }\end{array}$ \\
\hline & & & Pancreas NEC large cell type & & $\begin{array}{l}\text { Pancreas NEC } \\
\text { large cell type }\end{array}$ \\
\hline Uterus & Neuroendocrine & Neuroendocrine & Uterine NET & G1 & Carcinoid \\
\hline $\begin{array}{l}\text { (corpus } \\
\text { and cervix) }\end{array}$ & neoplasm (NEN) & tumor (NET) & & $\begin{array}{l}\text { G2 } \\
\text { G3 }\end{array}$ & $\begin{array}{l}\text { Atypical carcinoid } \\
\text { Atypical carcinoid }\end{array}$ \\
\hline & & Neuroendocrine & Uterine NEC small cell type & & Small cell carcinoma \\
\hline & & carcinoma (NEC) & Uterine NEC large cell type & & Large cell NE carcinoma \\
\hline
\end{tabular}

Lung, Pancreas and Uterus data adapted, under the terms of the original Creative Commons Attribution 4.0 International License from Rindi et al. $(2018 a)$.

aH\&N: Head and neck; bThe category of G3 atypical carcinoid in the lung need further study. High-grade NETs with features similar to the G3 NETs of the pancreas and gut are rare in the lung and currently classified as small cell lung carcinoma (SCLC) or large cell neuroendocrine carcinoma (LCNEC) (Travis et al. 2015); cNot recommended: the definition of small cell lung carcinoma (SCLC) is recommended since well ingrained in clinical practice and some SCLC lack commonly used neuroendocrine markers (Rudin et al. 2019a,b); dSite stands for the adjective connoting the different districts of the tubular gut where the NEN develops, that is, esophageal, gastric, duodenal, small intestinal, appendiceal, colonic, rectal and anal canal NET or NEC.

https://erc.bioscientifica.com https://doi.org/10.1530/ERC-20-0036 (c) 2020 Society for Endocrinology Published by Bioscientifica Ltd. Printed in Great Britain 
historical definitions that reflect site-specific features but may generate confusion and mismanagement. What is now being attempted is the translation of such contents into a more rationale classification framework with specific definitions (NEN as cancer category, NET and NEC as cancer classes) and a proliferation-based grading system tool (Table 2).

The identification of simple and uniform neoplasm classifiers together with grading tools aims to capture the essential information needed to direct the clinical patient management and therapy. Much work is still needed in translating current knowledge into the proposed classifier and this novel grading tool. This will entail collecting large amounts of cases uniformly classified and studied.

It is thus recommended adopting this novel frame in all conditions of recognized NEN patient, to identify, define and report the novel classifiers together with those currently in use and traditionally known. Coupling this information will help to generate the data needed to support a potentially more informative classification of NEN. Most importantly, the recognition of the neuroendocrine cancer classes will hopefully help in the understanding and development of equally informative genetic classifiers for NEN across different organs.

\section{Declaration of interest}

$G$ R received speaker's honoraria from Ipsen and Novartis. F I declares no competing interests.

\section{Funding}

This work was, in part, supported by internal university grant to G R (Università Cattolica line D.1 2017-R4124500591).

\section{Author contribution statement}

Both authors equally contributed to the conceptualization, referencing and writing of the text. The authors thank Dr Sammy Faris for manuscript revision and English editing.

\section{References}

Alcala N, Leblay N, Gabriel AAG, Mangiante L, Hervas D, Giffon T, Sertier AS, Ferrari A, Derks J, Ghantous A, et al. 2019 Integrative and comparative genomic analyses identify clinically relevant pulmonary carcinoid groups and unveil the supra-carcinoids. Nature Communication 10 3407. (https://doi.org/10.1038/s41467-019-11276-9)

Asa SL, Casar-Borota O, Chanson P, Delgrange E, Earls P, Ezzat S, Grossman A, Ikeda H, Inoshita N, Karavitaki N, et al. 2017 From pituitary adenoma to pituitary neuroendocrine tumor (PitNET): an International Pituitary Pathology Club proposal. Endocrine-Related Cancer 24 C5-C8. (https://doi.org/10.1530/ERC-17-0004)

Asa SL, Asioli S, Bozkurt S, Casar-Borota O, Chinezu L, Comunoglu N, Cossu G, Cusimano M, Delgrange E, Earls P, et al. 2020 Pituitary neuroendocrine tumors (PitNETs): nomenclature evolution, not clinical revolution. Pituitary 23 322-325. (https://doi.org/10.1007/ s11102-019-01015-0)

Chiloiro S, Bianchi A, Doglietto F, de Waure C, Giampietro A, Fusco A, Iacovazzo D, Tartaglione L, Di Nardo F, Signorelli F, et al. 2014 Radically resected pituitary adenomas: prognostic role of Ki 67 labeling index in a monocentric retrospective series and literature review. Pituitary 17 267-276. (https://doi.org/10.1007/s11102-0130500-6)

Chiloiro S, Doglietto F, Trapasso B, Iacovazzo D, Giampietro A, Di Nardo F, de Waure C, Lauriola L, Mangiola A, Anile C, et al. 2015 Typical and atypical pituitary adenomas: a single-center analysis of outcome and prognosis. Neuroendocrinology 101 143-150. (https:// doi.org/10.1159/000375448)

Dasari A, Shen C, Halperin D, Zhao B, Zhou S, Xu Y, Shih T \& Yao JC 2017 Trends in the incidence, prevalence, and survival outcomes in patients with neuroendocrine tumors in the United States. JAMA Oncology 3 1335-1342. (https://doi.org/10.1001/ jamaoncol.2017.0589)

DeLellis RA, Lloyd RV, Heitz PU \& Eng C 2004 Pathology and Genetics of Tumours of Endocrine Organs. Lyon, France: IARC Press.

Dermawan JKT \& Farver CF 2020 The role of histologic grading and Ki-67 index in predicting outcomes in pulmonary carcinoid tumors. American Journal of Surgical Pathology 44 224-231. (https://doi. org/10.1097/PAS.0000000000001358)

Dinter H, Bohnenberger H, Beck J, Bornemann-Kolatzki K, Schutz E, Kuffer S, Klein L, Franks TJ, Roden A, Emmert A, et al. 2019 Molecular classification of neuroendocrine tumors of the thymus. Journal of Thoracic Oncology 14 1472-1483. (https://doi.org/10.1016/j. jtho.2019.04.015)

El-Naggar AK, Chan JKC, Grandis JR, Takata T \& Slootweg PJ 2017 WHO Classification of Head and Neck Tumours. Lyon, France: IARC Press.

Elder DE, Massi D, Scolyer RA \& Willemze R 2018 WHO Classification of Skin Tumours. Lyon, France: IARC Press.

Feyrter F 1938 Uber diffuse endokrine epitheliale organe. Zentralblatt für innere Medizin 545 31-41.

Gehart H, van Es JH, Hamer K, Beumer J, Kretzschmar K, Dekkers JF, Rios A \& Clevers H 2019 Identification of enteroendocrine regulators by real-time single-cell differentiation mapping. Cell 1761158. e1116-1173.e1116. (https://doi.org/10.1016/j.cell.2018.12.029)

Ho KKY, Fleseriu M, Wass J, van der Lely A, Barkan A, Giustina A, Casanueva FF, Heaney AP, Biermasz N, Strasburger C, et al. 2019 A tale of pituitary adenomas: to NET or not to NET: Pituitary Society position statement. Pituitary 22 569-573. (https://doi.org/10.1007/ s11102-019-00988-2)

Ho KKY, Fleseriu M, Wass J, van der Lely A, Barkan A, Giustina A, Casanueva FF, Heaney AP, Biermasz N, Strasburger C, et al. 2020 The tale in evolution: clarity, consistency and consultation, not contradiction and confusion. Pituitary [epub]. (https://doi. org/10.1007/s11102-019-01027-w)

ICGC/TCGA Pan-Cancer Analysis of Whole Genomes Consortium 2020 Pan-cancer analysis of whole genomes. Nature 578 82-93. (https:// doi.org/10.1038/s41586-020-1969-6)

Inzani F \& Rindi G 2017 Classification of neuroendocrine neoplasms. In Diagnostic and Therapeutic Nuclear Medicine for Neuroendocrine Tumors, pp 1-13. Ed PKaT D. Cham, Switzerland: Springer International Publishing.

Jesinghaus M, Konukiewitz B, Keller G, Kloor M, Steiger K, Reiche M, Penzel R, Endris V, Arsenic R, Hermann G, et al. 2017 Colorectal mixed adenoneuroendocrine carcinomas and neuroendocrine
2020 Society for Endocrinology Published by Bioscientifica Ltd. Printed in Great Britain 
carcinomas are genetically closely related to colorectal adenocarcinomas. Modern Pathology 30 610-619. (https://doi. org/10.1038/modpathol.2016.220)

Kasajima A, Konukiewitz B, Oka N, Suzuki H, Sakurada A, Okada Y, Kameya T, Ishikawa Y, Sasano H, Weichert W, et al. 2019 Clinicopathological profiling of lung carcinoids with a Ki67 index $>20$. Neuroendocrinology 108 109-120. (https://doi. org/10.1159/000495806)

Kloppel G 2017 Neuroendocrine neoplasms: dichotomy, origin and classifications. Visceral Medicine 33 324-330. (https://doi. org/10.1159/000481390)

Konukiewitz B, Schlitter AM, Jesinghaus M, Pfister D, Steiger K, Segler A, Agaimy A, Sipos B, Zamboni G, Weichert W, et al. 2017 Somatostatin receptor expression related to TP53 and RB1 alterations in pancreatic and extrapancreatic neuroendocrine neoplasms with a Ki67-index above 20. Modern Pathology 30 587-598. (https://doi.org/10.1038/ modpathol.2016.217)

Laddha SV, da Silva EM, Robzyk K, Untch BR, Ke H, Rekhtman N, Poirier JT, Travis WD, Tang LH \& Chan CS 2019 Integrative genomic characterization identifies molecular subtypes of lung carcinoids. Cancer Research 79 4339-4347. (https://doi.org/10.1158/0008-5472. CAN-19-0214)

Lloyd RV, Osamura R, Kloppel G \& Rosai J 2017 WHO Classification of Tumours of Endocrine Organs. Lyon, France: IARC Press.

Moch H, Humphrey PA, Ulbright TM \& Reuter VE 2016 WHO Classification of Tumours of the Urinary System and Male Genital Organs. Lyon, France: IARC Press.

Neou M, Villa C, Armignacco R, Jouinot A, Raffin-Sanson ML, Septier A, Letourneur F, Diry S, Diedisheim M, Izac B, et al. 2020 Pangenomic classification of pituitary neuroendocrine tumors. Cancer Cell 37 123.e125-134.e125. (https://doi.org/10.1016/j. ccell.2019.11.002)

Oka N, Kasajima A, Konukiewitz B, Sakurada A, Okada Y, Kameya T, Weichert W, Ishikawa Y, Suzuki H, Sasano H, et al. 2019 Classification and prognostic stratification of bronchopulmonary neuroendocrine neoplasms. Neuroendocrinology 110 393-403. (https://doi.org/10.1159/000502776)

Priestley P, Baber J, Lolkema MP, Steeghs N, de Bruijn E, Shale C, Duyvesteyn K, Haidari S, van Hoeck A, Onstenk W, et al. 2019 Pancancer whole-genome analyses of metastatic solid tumours. Nature 575 210-216. (https://doi.org/10.1038/s41586-019-1689-y)

Raj N, Shah R, Stadler Z, Mukherjee S, Chou J, Untch B, Li J, Kelly V, Saltz LB, Mandelker D, et al. 2018 Real-time genomic characterization of metastatic pancreatic neuroendocrine tumors has prognostic implications and identifies potential germline actionability. JCO Precision Oncology 2018 [epub]. (https://doi. org/10.1200/PO.17.00267)

Rekhtman N, Pietanza MC, Hellmann MD, Naidoo J, Arora A, Won H, Halpenny DF, Wang H, Tian SK, Litvak AM, et al. 2016 Nextgeneration sequencing of pulmonary large cell neuroendocrine carcinoma reveals small cell carcinoma-like and non-small cell carcinoma-like subsets. Clinical Cancer Research 22 3618-3629. (https://doi.org/10.1158/1078-0432.CCR-15-2946)

Rickman DS, Beltran H, Demichelis F \& Rubin MA 2017 Biology and evolution of poorly differentiated neuroendocrine tumors. Nature Medicine 23 1-10. (https://doi.org/10.1038/nm.4341)

Rindi G \& Wiedenmann B 2012 Neuroendocrine neoplasms of the gut and pancreas: new insights. Nature Reviews Endocrinology 8 54-64. (https://doi.org/10.1038/nrendo.2011.120)

Rindi G, Klimstra DS, Abedi-Ardekani B, Asa SL, Bosman FT, Brambilla E, Busam KJ, de Krijger RR, Dietel M, El-Naggar AK, et al. 2018a A common classification framework for neuroendocrine neoplasms: an International Agency for Research on Cancer (IARC) and World Health Organization (WHO) expert consensus proposal. Modern Pathology 31 1770-1786. (https://doi.org/10.1038/s41379-0180110-y)

Rindi G, Klersy C, Albarello L, Baudin E, Bianchi A, Buchler MW, Caplin M, Couvelard A, Cros J, de Herder WW, et al. $2018 b$ Competitive testing of the WHO 2010 versus the WHO 2017 grading of pancreatic neuroendocrine neoplasms: data from a large international cohort study. Neuroendocrinology 107 375-386. (https:// doi.org/10.1159/000494355)

Rudin CM, Poirier JT, Byers LA, Dive C, Dowlati A, George J, Heymach JV, Johnson JE, Lehman JM, MacPherson D, et al. 2019a Author correction: Molecular subtypes of small cell lung cancer: a synthesis of human and mouse model data. Nature Reviews Cancer 19 415. (https://doi.org/10.1038/s41568-019-0164-2)

Rudin CM, Poirier JT, Byers LA, Dive C, Dowlati A, George J, Heymach JV, Johnson JE, Lehman JM, MacPherson D, et al. $2019 b$ Molecular subtypes of small cell lung cancer: a synthesis of human and mouse model data. Nature Reviews Cancer 19 289-297. (https:// doi.org/10.1038/s41568-019-0133-9)

Shamir ER, Devine WP, Pekmezci M, Umetsu SE, Krings G, Federman S, Cho SJ, Saunders TA, Jen KY, Bergsland E, et al. 2019 Identification of high-risk human papillomavirus and $\mathrm{Rb}$ /E2F pathway genomic alterations in mutually exclusive subsets of colorectal neuroendocrine carcinoma. Modern Pathology 32 290-305. (https:// doi.org/10.1038/s41379-018-0131-6)

Travis WD, Brambilla E, Burke AP, Marx A \& Nicholson AG 2015 Pathology and Genetics of Tumours of the Lung, Pleura, Thymus and Heart. Lyon, France: IARC Press.

WHO Classification of Tumours Editorial Board 2019a WHO Classification of Tumours. Breast Tumors. Lyon, France: IARC Press.

WHO Classification of Tumours Editorial Board 2019b WHO Classification of Tumours. Digestive System Tumours. Lyon, France: IARC Press.

Woischke C, Schaaf CW, Yang HM, Vieth M, Veits L, Geddert H, Markl B, Stommer P, Schaeffer DF, Frolich M, et al. 2017 In-depth mutational analyses of colorectal neuroendocrine carcinomas with adenoma or adenocarcinoma components. Modern Pathology 30 95-103. (https://doi.org/10.1038/modpathol.2016.150)

Received in final form 18 March 2020

Accepted 9 April 2020

Accepted Manuscript published online 9 April 2020
C) 2020 Society for Endocrinology Published by Bioscientifica Ltd. Printed in Great Britain 